\title{
Enterobius vermicularis infection in preschool and schoolchildren of six rural communities from a semiarid region of Venezuela: a clinical and epidemiological study
}

\author{
D. CAZORLA*, M. ACOSTA, E. GARCÍA ${ }^{1}$, M. GARVETT ${ }^{1}$, A. RUIZ
}

\begin{abstract}
Laboratorio de Entomología, Parasitología y Medicina Tropical, Centro de Investigaciones Biomèdicas, Universidad Nacional Experimental "Francisco de Miranda", Apartado Postal 7403, Coro 4101, Estado Falcòn, Venezuela, E-mail: Lutzomyia@hotmail.com; ${ }^{1}$ Hospital Universitario “Alfredo Van Grieken”, Coro, Estado Falcón, Venezuela
\end{abstract}

\begin{abstract}
Summary
Between August 2001 and July 2002, a cross-sectional survey was conducted to investigate clinical and epidemiological data on pinworm infection among 427 preschool and primary school age children of six rural communities from the semiarid region of Falcon state, northwestern Venezuela. Children were evaluated clinically and parasitologically by the Graham method. Overall prevalence was high $(63.23 \%)$. Pinworm infection rates were not significantly different between sex or age, suggesting similar transmission pattern and risk conditions for all individuals. Among the clinical findings and children's habits, only perianal itching, enuresis, bruxism, and finger sucking showed significant higher percentages in infected children than in uninfected. Of interest was that anal pruritus (odds ratio [OR], 2.441), finger sucking (OR, 1.901), lower socioeconomic levels (OR, 4.358) and high levels of overcrowding conditions ( $\geq 3$ persons/room: OR, 1.878; $\geq 2$ persons/bed: OR, 11.833) appeared to be significant factors associated with transmission and endemic maintenance of enterobiasis among student children in this semi-arid Venezuelan region.
\end{abstract}

Key words: Enterobius vermicularis; epidemiology; clinical manifestations; children; Venezuela

\section{Introduction}

Enterobius vermicularis (L.) (= oxyurus, pinworm) is the causative agent of human enterobiasis (= oxyuriasis). Although successful and effective antihelminthic drugs have been available for decades, oxyuriasis still remains one of the major helminthic diseases of public health importance, affecting approximately 1 billion people worldwide, predominantly in school aged children (Cook, 1994; Gren- cis \& Cooper, 1996). This parasitic disease is prevalent in both temperate and tropical climates, and virtually all socioeconomic level groups, both in developing and developed countries (Haswell-Helkins et al., 1987). In the case of Venezuela, the impression is felt that enterobiasis has been considered a minor public health problem, judging by the low availability of epidemiological data or studies, and probably by the common and pejorative belief that infection only causes a "simple pruritis ani". In addition, its transmission is facilitated by several factors such as family and school overcrowding, as well as inadequate personal and community hygiene habits, and rapidity of the reinfection and autoinfection process (Botero \& Restrepo, 1984). Typically, enterobiasis is asymptomatic, but its most common clinical manifestation, intense anal pruritus, may lead to insomnia, restlessness and irritability in some individuals, especially children, and possibly affecting negatively their academic performance by attention disturbance. Scratching may often cause skin irritation, with subsequent dermatitis, haemorrhage or secondary bacterial infections (Botero \& Restrepo, 1984; Cook, 1994).

Although a rare occurrence, female pinworm may also eventually invade the human female genital tract, causing vaginitis or granulomes in the pelvic peritoneum, uterus, ovary, and fallopian tubes (Erhan et al., 2000; Smolyakov et al., 2003). Additionally, in recent studies pinworm infection has been involved adversely affecting serum level micronutrients, vitamin $\mathrm{B}_{12}$ and intelligence quotient in children (Bahader et al., 1995; Koltas et al., 1997; Olivares et al., 2002).

As part of a global project under current implementation aimed to search deleterious effects of intestinal helminthiasis on anthropometric measurements and cognitive capacity in student children from Falcon state's semiarid re-

\footnotetext{
* Corresponding author
} 
gion in northwestern Venezuela, we present here the results of a clinic-epidemiological survey on enterobiasis carried out in preschool and school children of six rural communities from this semiarid region of northwestern Venezuela.

\section{Materials and Methods}

From August 2001 to July 2002, a cross-sectional survey was conducted in 427 children (223 girls and 204 boys) of six kindergarten $(n=210)$ and two primary schools $(n=$ 217) belonging to six rural communities located in Falcon state at $8^{\circ} 20^{\prime}-11^{\circ} 56^{\prime} \mathrm{N}$ and $68^{\circ} 00^{\prime}-71^{\circ} 59^{\prime} \mathrm{W}$, in a semiarid region of northwestern Venezuela which includes Codore, Zazárida Ocorote, Río Seco, San Gregorio and Cabecera, whose ecological, floristic and climatic characteristics were given in a previous paper (Acosta et al., 2002). The majority of these rural communities are completely devoid of basic sanitation and piped water supply, and especially children defecate at any site other than latrines, even if available. All children attending kindergarten and primary school were studied. Informed consent to join the study was obtained from both the directors of educational centres and children's parents.

The pinworm infection diagnosis was made using the cellotape anal swab technique, which was performed once in the early morning before the children's first bowel movement and personal sanitation. After the anal swab examination, medication was provided to parasitized children.

Children were clinically examined to detect symptoms commonly attributed to E. vermicularis infection, including among others, anal pruritus, perianal lesions, enuresis, vulvitis and bruxism (teeth grinding). Children's habits such as finger sucking and geophagy were also investigated.

A questionnaire was provided to each child's parents with questions about their socioeconomic status and the family's overcrowding conditions $(\mathrm{n}=317)$, including persons per room ( $\mathrm{p} / \mathrm{r})$ and persons sharing a bed $(\mathrm{p} / \mathrm{b})$. A family with $\geq 3 \mathrm{p} / \mathrm{r}$ and/or $\geq \mathrm{p} / \mathrm{b}$ was considered as having overcrowding conditions. Socioeconomic level was determined by a modification of the Graffar Index method, a standardised methodology generally accepted worldwide to establish different socioeconomic strata, and adapted to the Venezuelan population (Méndez-Castellanos et al., 1986)

Identification of risk factors and variables potentially associated with enterobiasis were evaluated using the Chi Square $\left(\mathrm{X}^{2}\right)$ test. Logistic regression analysis was used to calculate any association strength between $E$. vermicularis infection and potential variables or risk factors by odds ratio (OR) and $95 \%$ confidence interval. Statistical significance was defined as $\mathrm{p}<0.05$. Data were analysed by MINITAB version 13.20 (MiniTab Inc., 2000), and G-stat version 1.2 (Glaxo Smith Kline, S.A., 2003).

\section{Results}

The overall egg positive rate for E. vermicularis was 63.23 $\%(270 / 427)$. All children of 6 to 12 years old (54.07 vs. $45.93 \%$ ) and particularly girls (55.56 vs. $44.44 \%$ ) showed the highest prevalences, however, pinworm infection rates as assessed by the $\mathrm{X}^{2}$ test were not statistically significant between preschool-aged and school-aged children $\left(\mathrm{X}^{2}=\right.$ 15.04; $\mathrm{p}=0.131)$, neither between sexes $\left(\mathrm{X}^{2}=2.92 ; \mathrm{p}=\right.$ 0.088 ) (Table 1). Perianal itching was the cardinal symptom, being prevalent in $41.22 \%$ of pinworm-infected children and in $15.93 \%$ of non-infected subjects. Except for perianal lesions, vulvitis, insomnia and geophagy, there was a significant association between prevalence of $E$. vermicularis infection and anal pruritus, bruxism, enuresis and finger sucking, as shown in Table 2. As expected, the Graffar analysis revealed that more than $88 \%(280 / 317)$ of the 317 families studied live under the threshold of poverty, and $41 \%$ of them show the lowest socioeconomic status

Table 1. Distribution of pinworm infection by age and sex among preschool and school children of six communities of Falcon state, Venezuela

\begin{tabular}{|c|c|c|c|c|}
\hline $\begin{array}{c}\text { Age } \\
\text { (years) }\end{array}$ & $n^{*}$ & $\begin{array}{l}\text { Female } \\
\mathrm{N}^{\circ}(\%)\end{array}$ & $\begin{array}{c}\text { Male } \\
\mathrm{N}^{\circ}(\%) \\
\end{array}$ & $\begin{array}{c}\text { Total } \\
\mathrm{N}^{\circ}(\%) \\
\end{array}$ \\
\hline 2 & 18 & $7(2.59)$ & $4(1.48)$ & $11(4.07)$ \\
\hline 3 & 63 & $22(8.15)$ & $14(5.19)$ & $36(13.33)$ \\
\hline 4 & 68 & $22(8.15)$ & $19(7.04)$ & $41(15.19)$ \\
\hline 5 & 61 & $21(7.78)$ & $15(5.56)$ & $36(13.33)$ \\
\hline Subtotal Preschool & 210 & $72(26.67)$ & $52(19.26)$ & $124(45.93)$ \\
\hline 6 & 31 & $7(2.59)$ & $12(4.44)$ & $19(7.04)$ \\
\hline 7 & 42 & $22(8.15)$ & $14(5.19)$ & $36(13.33)$ \\
\hline 8 & 38 & $18(6.67)$ & $6(2.22)$ & $24(8.89)$ \\
\hline 9 & 36 & $8(2.96)$ & $18(6.67)$ & $26(9.63)$ \\
\hline 10 & 38 & $15(5.56)$ & $9(3.33)$ & $24(8.89)$ \\
\hline 11 & 24 & $5(1.85)$ & $6(2.22)$ & $11(4.07)$ \\
\hline 12 & 10 & $3(1.11)$ & $3(1.11)$ & $6(2.22)$ \\
\hline Subtotal School & 217 & $78(28.89)$ & $68(25.19)$ & $146(54.07)$ \\
\hline Total & 427 & $150(55.56)$ & $120(44.44)$ & $270(100)$ \\
\hline
\end{tabular}

$* n=$ total number of children sampled in each group 
Table 2. Clinical findings and habits observed among 427 preschool and school children of six communities of Falcon state, Venezuela

\begin{tabular}{|c|c|c|c|c|}
\hline Clinical findings and habits & $\begin{array}{l}\text { Infected } \\
\mathrm{N}^{\circ}(\%)\end{array}$ & $\begin{array}{c}\text { Non-infected } \\
\mathrm{N}^{\circ}(\%)\end{array}$ & $X^{2}$ & $p$-value \\
\hline Anal pruritus & $176(41.22)$ & $68(15.93)$ & 19.349 & 0.00001 \\
\hline Perianal lesions & $68(15.93)$ & $34(7.96)$ & 0.680 & 0.410 \\
\hline Bruxism & $165(38.64)$ & $77(18.03)$ & 5.873 & 0.015 \\
\hline Enuresis & $124(29.04)$ & $48(11.24)$ & 6.11 & 0.014 \\
\hline Vulvitis & $86(20.14)$ & $53(12.41)$ & 0.164 & 0.686 \\
\hline Insomnia & $80(18.74)$ & $46(10.77)$ & 0.005 & 0.943 \\
\hline Geopahgy & $148(34.66)$ & $83(19.44)$ & 0.151 & 0.697 \\
\hline Finger sucking & $56(13.12)$ & $19(4.45)$ & 5.105 & 0.024 \\
\hline
\end{tabular}

Table 3. Overcrowding conditions and socioeconomic level of households in six communities of Falcon state, Venezuela

\begin{tabular}{|c|c|c|c|c|}
\hline & $\begin{array}{c}\text { Household }^{+} \\
\text {non positives } \\
\mathrm{N}^{\circ}(\%) \\
\end{array}$ & $\begin{array}{c}\text { Household }^{+} \\
\text {positives } \\
\mathrm{N}^{\circ}(\%) \\
\end{array}$ & $X^{2}$ & $p$-value \\
\hline \multicolumn{5}{|c|}{ Overcrowding conditions } \\
\hline \multicolumn{5}{|c|}{ Persons/room } \\
\hline$\geq 3 \mathrm{p} / \mathrm{r}^{*}$ & $86(27.13)$ & $153(48.27)$ & 5.126 & 0.024 \\
\hline$<3 \mathrm{p} / \mathrm{r}^{*}$ & $40(12.62)$ & 38 (11.99) & & \\
\hline \multicolumn{5}{|c|}{ Persons/bed } \\
\hline$\geq 2 \mathrm{p} / \mathrm{b}^{* *}$ & $45(14.20)$ & $164(51.74)$ & 82.784 & 0.00001 \\
\hline $1 \mathrm{p} / \mathrm{b}^{* *}$ & $81(25.55)$ & $27(8.52)$ & & \\
\hline \multicolumn{5}{|c|}{ Socio-economic level (Graffar) } \\
\hline I. II. III & $36(11.36)$ & $11(3.47)$ & 14.884 & 0.0001 \\
\hline IV. V & $90(28.39)$ & $180(56.78)$ & & \\
\hline
\end{tabular}

+ Total of households $=317 ; *$ persons per room; $* *$ persons per bed

Table 4. Odds ratios (OR) from logistic regression analysis for factors potentially associated with E. vermicularis infection, among preschool and school aged children in six communities of Falcon state, Venezuela

\begin{tabular}{|c|c|c|c|}
\hline Variable & Coefficient & SE & OR (95\% Confidence Interval) \\
\hline Anal pruritus & 0.8767 & 0.3190 & $2.441(1.6134-3.556)$ \\
\hline Finger sucking & 0.6199 & 0.4340 & $1.901(1.011-3.323)$ \\
\hline \multicolumn{4}{|l|}{ Overcrowding } \\
\hline $\begin{array}{l}\geq 3 \mathrm{p} / \mathrm{r}^{*} \\
<3 \mathrm{p} / \mathrm{r}^{*}\end{array}$ & 0.5932 & 0.4139 & $1.878(1.734-3.219)$ \\
\hline$\geq 2 \mathrm{p} / \mathrm{b}^{* *}$ & 2.3591 & 0.8987 & $11.833(6.441-18.991)$ \\
\hline \multicolumn{4}{|c|}{$1 \mathrm{p} / \mathrm{b}^{* *}$} \\
\hline \multicolumn{4}{|c|}{ Socio-economic Level (Graffar scale) } \\
\hline \multicolumn{4}{|c|}{ I, II, III } \\
\hline IV, V & 1.4564 & 0.5211 & $4.358(2.119-8.975)$ \\
\hline
\end{tabular}

* Persons per room; ** Persons per bed

(level V) (Table 3 ). In relation to overcrowding conditions, $75.39 \%$ of families were registered with 3 or more (up to 13) persons sharing a room $(\mathrm{p} / \mathrm{r})$, and $65.93 \%$ with 2 or more (up to 3 ) persons sharing a bed ( $\mathrm{p} / \mathrm{b})$. Overcrowding ( $\geq 3 \mathrm{p} / \mathrm{r}$ and/or $\geq 2 \mathrm{p} / \mathrm{b}$ ) and the poorer strata (IV, V) in the Graffar index were found to be significantly associated with enterobiasis (Table 4). From the variables studied, potential risk factors for acquiring $E$. vermicularis infection appear to be, as suggested by their higher ORs (Table 4), anal pruritus (OR, 2.441), finger sucking (OR, 1.901), overcrowding ( $\geq 3 \mathrm{p} / \mathrm{r}$, OR, $1.878 ; \geq 2 \mathrm{p} / \mathrm{b}$, OR, 11.833) and lower socioeconomic level (IV, V) of the family (OR, 4.358).

\section{Discussion}

Results from the clinic-epidemiological survey showed a high overall prevalence of pinworm infection of $63.25 \%$ 
in preschool and school aged children in the six communities studied, confirming our previous observations (Acosta et al., 2002) that E. vermicularis is a highly prevalent helminth in the school communities of Falcon state's semiarid region in northwestern Venezuela. These observations clearly indicate major problems in basic hygiene, sanitation and poverty conditions, and are supported by the finding of $88.33 \%$ of families in the IV and V strata of the Graffar analysis and the significant association between oxyuriasis and lower socioeconomic status. In addition, these epidemiological data add support to the view of Haswell-Elkins et al. (1987) that E. vermicularis is a highly successful parasite in tropical areas, instead of the past misconception that this helminth was more prevalent in temperate regions due to less frequent bathing and clothes washing observed in colder climates.

Epidemiological surveys on enterobiasis in Venezuela are frankly scarce, most likely for considering pinworm infection an issue of lesser concern. Contrasting the Venezuelan rural communities of Falcon state's semiarid region, in 477 urban preschool and school children surveyed from a South-eastern region of the country, has been reported a strikingly lower infection rate of $21.80 \%$ (Devera et al., 1998; Requena-Certad et al., 2002).

Despite massive antihelminthic medication (mebendazole) periodically supplied by sanitary and educational authorities, paradoxically pinworm infection rates remain endemically high in the school population from this semiarid region. A possible explanation: E. vermicularis presents a prepatent period of 1 month and eggs reach adult stage in about 14 days; for other part, mebendazole is ineffective against the nematode's eggs and larvae. Therefore, a second application of antiworm medication, 14 days later, as a general rule should be mandatory to clear up the infection completely (Kastner et al., 1992; Cook, 1994; Lohiya et al., 2000). Likewise, it should be emphasised that, unlike human geohelminths that mature in the soil, pinworm is very contagious, being easily spread from one person to another. In fact, in the present study it was demonstrated that the majority of families exhibit a high degree of overcrowding (persons per room or bed), which was significantly associated with enterobiasis. Therefore, the home in this semiarid region of Venezuela, where up to 13 or 3 persons share one room or bed, respectively, appeared to be an important source of pinworm infection via person-toperson, and probably of reinfection for children.

As already mentioned in a previous paper (Acosta et al., 2002), this semiarid region's eroded soils are subjected to constant surface trade winds, which spread sand and dust, especially inside rural households. Thus, airborne transmission by inhaling pinworm eggs, which remain $2-3$ weeks viable in dust or surfaces, as well as fomite contamination, must be important factors in the epidemiology of this helminthic infection (Engelbrecht \& Berendt, 1991; Hugot et al., 1999).

Several authors have found enterobiasis prevalence to be significantly higher in school aged children than in children of $2-5$ years (Cook, 1994; Gilman et al., 1991; Song et al., 2003), but the present study shows no statistically significant differences between the two age groups, nor in boys or girls, suggesting similar transmission patterns and risk conditions for acquiring pinworm eggs in all individuals.

Anal pruritus was the most common symptom detected, being significantly associated with $E$. vermicularis infection, whose eggs need about 6 hours for hatching in the anus (Cram, 1943). Anal pruritus plus finger sucking, a child behaviour also found to be significantly associated with enterobiasis, could increase the rate of anal-oral contamination, especially in the communities of this semiarid Venezuelan region which suffer a remarkable scarcity of water, further decreasing the frequency of familiar and personal hygiene, including elementary hand washing.

$\mathrm{X}^{2}$ analysis revealed a significant association between secondary enuresis, bruxism and enterobiasis. Although these two symptoms are usually attributed to E. vermicularis infection (Gilman et al., 1991), their association with this enteric worm is unclear and controversial, thus requiring further controlled studies.

The results of the present clinic-epidemiologic survey showed that there are several factors significantly associated with pinworm transmission in the semiarid Venezuelan region, such as poor socioeconomic and overcrowding living conditions as well as children' unhygienic behaviours (e.g., finger-sucking). Hence, public health authorities should design public health interventions to reduce and prevent pinworm incidence using the knowledge of these factors, coupled with periodic deworming of children with anthelmintic drugs. These health interventions include: health promotion education, with adoption of hygienic knowledge, attitudes and practices, as well as improvement of physical environment in both schools and households, with adequate sanitary facilities and a safe water supply.

\section{Acknowledgments}

We are grateful to Dr. D. Candelle and Dr. J. Eizaga for critically reading the manuscript. Grant: 2002.008.

\section{References}

Acosta, M., Cazorla, D., Garvett, M. (2002): Enterobiasis among schoolchildren in a rural population from Estado Falcon, Venezuela, and its relation with socioeconomic level. Invest. Clin., 43: 173 - 181

Bahader, S., Ali, G., SAlan, A., Khalil, H., Kahlil, N. (1995): Effects of Enterobius vermicularis infection on intelligence quotient (IQ) and anthropometric measurements of Egyptian rural children. J. Egypt. Soc. Parasit., 25: 183 $-194$

Botero, D., Restrepo, M. (1984): Human Parasitoses. Corporation for Biological Research, Medellín, Colombia CooK, G. (1994): Enterobius vermicularis. Gut., 35: 1159 $-1162$

CRAM, E. (1943): Studies on oxyuriasis. XXVIII. Summaries and conclusions. Am. J. Dis. Chile, 65: 46-59 
Devera, R., Perez, C., Ramos, Y. (1998). Enterobiasis in students from Ciudad Bolivar, Venezuela. Bol. Chil. Parasitol., 53: $14-18$

Engelbrecht, H., BerendT, H. (1991): The eggs of Enterobius vermicularis in room dust. I. Methods. Angew. Parasit., 32: $15-19$

Erhan, Y., Zekioglu, O., Ozdemir, N., Sen, S. (2000): Unilateral salpingitis due to Enterobius vermicularis. Int. J. Gyneco. Pathol., 19: 188 - 189

Gilman, R., MARQuis, G., Miranda, E. (1991): Prevalence and symptoms of Enterobius vermicularis infections in a Peruvian shanty town. Trans. R. Soc. Trop. Med. Hyg., 85: $761-764$

Grencis, R., COOPER, E. (1996): Enterobius, Trichuris, Capillaria and hookworm. Gastroenterol. Clin. North. Am., 25: 579 - 596

Haswell-Helkins, M., Elkins, D., Manjula, K., MiCHAEL, E., ANDERSON, R. (1987): The distribution and abundance of Enterobius vermicularis in a South Indian fishing community. Parasitology, 95: 339 - 354

Hugot, J., Reinhard, K., Gardner, S., Morand, S. (1999): Human enterobiasis in evolution: origin, specificity and transmission. Parasite, 6: $201-208$

Kastner, T., Selvaggi, K., Cowper, R. (1992): Pinworm eradication in community residential settings for people with developmental disabilities. Ment. Retard., 30: 237 240

RECEIVED JANUARY 25, 2005
Koltas, I., Ozcan, K., Tamer, M., Aksungur, P. (1997) Serum copper, zinc and magnesium levels in children with enterobiasis. J. Trace. Elem. Med. Biol., 11: 49 - 52

LOHIYA, G., TAN-FigueroA, L., Crinella, F., LOHIYA, S. (2000): Epidemiology and control of enterobiasis in a developmental center. West J. Med., 172: $305-308$

MÉndez-Castellanos, H., LóPez, M., Landaeta, M., GonZÁlez, A. (1986): Transversal study of Caracas. Arch. Venez. Pueric. Pediatr., 49: $111-115$

Olivares, J., Fernández, R., Fleta, J., Ruiz, M., ClAVEL, A. (2002): Vitamin $B_{12}$ and folic acid in children with intestinal parasitic infection. J. Amer. Coll. Nutr., 21: $109-$ 113

Requena-Certad, I., Lizardi, V., Mejía, L., Castillo, H., DEVERA, R. (2002): Enterobius vermicularis infection in preschool children from Ciudad Bolívar, Venezuela. Rev. Biomed., 13: $231-240$

Smolyakov, R., Talayay B., YAnai-Inbar I., PARK I., ALKAN, M. (2003): Enterobius vermicularis infection of female genital tract: a report of three cases and review of literature. Eur. J. Obstet. Gynecol. Reprod. Biol., 107: 220 $-222$

Song, H., ChO, C., KIM, J., CHOI, M., Hong, S. (2003): Prevalence and risk factors for enterobiasis among preschool children in a metropolitan city in Korea. Parasit. Res., 91: $41-50$

ACCEPTED MARCH 20, 2006 